\title{
INTEGRATION OF INTERFAITH HARMONY INTO MADRASSA CURRICULUM IN PAKISTAN: A STEP TO SUSTAINABLE DEVELOPMENT
}

\author{
Zia ul Haq \\ Asst. Prof. Dr., College of Shari'ah \& Islamic Studies, University of Sharjah, UAE, email: \\ zulhaq@sharjah.ac.ae
}

\begin{abstract}
What students learn has a tremendous impact on their future thinking, behavior, and view on life. A curriculum should symbolize a society's vision for its future and should be evaluated on a regular basis in response to new challenges and changing scenarios. There are growing concerns about the Madrassa (Religious seminaries) curricula and its negative role in imparting interfaith harmony in Pakistan. There is growing concern regarding the curricula of Madrassas (religious seminaries) and their negative impact on interfaith cooperation in Pakistan. Opponents believe that the current Madrassa Curriculum ignores Islam's spiritual beauty and does not include any information on human rights. The current curricula of Religious seminaries do not devote enough emphasis to Figh al Aqaliat (Islamic law for minorities), which is a crucial subject in Islamic Jurisprudence and worth reading. It's worth noting that today's religious disputes have given way to civilizational clashes, and religion will continue to be a major source of conflict both within and between nations for the foreseeable future. As Berghout points out, if people are unwilling to accept and tolerate difference, the already perilous situations aggravated by religious intolerance in many parts of the world will erupt. ${ }^{1}$ In locations where many cultures and religions mix, such as the Indian subcontinent, conflict is more likely. Such conflicts, on the other hand, can be avoided if adequate mechanisms for ensuring religious peace are created and implemented early on. In accordance with the UNESCO goal of education for sustainable development, these efforts include urgent educational reforms and curricular improvements. The goal of this study is to assess present religious' curricula in terms of interfaith harmony through comprehensive content analysis as well as to improve existing curricula by including new topics and strategies. The study demonstrates the madrasa courses to have numerous flaws and deficiencies, and recommends measure to improve them, including increased coverage of interfaith cohabitation. After describing the shortcomings of Madrasa curricula, the researcher suggests ways to improve their quality in order to achieve long-term peace and interfaith collaboration in today's society.
\end{abstract}

Keywords: Interfaith Harmony, Curriculum Development, Madrassa' Curriculum, Religious Education, Pakistan, Sustainable Development

\section{INTRODUCTION}

All religions are founded on the concepts of human unity, peace, and harmony and that we should love and assist one another in order to coexist peacefully and to live joyfully in a friendly sustainable world. All religions emphasize the preaching of peace, tolerance, and mutual understanding. Tragically, today religion has evolved into a major source of bloodshed around the world, most notably in the Muslim World. Religious

\footnotetext{
1 Berghout, A. 2008. Meeting the challenges of dialogue: Need for civilisational vision and culturaltransformation. In Dialogue of civilizations and the construction of peace". Kuala Lumpur: Pusat Dialog Peradaban, Universiti Malaya
} 
conflicts have given way to clashes of civilizations, and religion is set to remain a major cause of conflict both within and between nations for the foreseeable future. As Berghout puts out, if people are unwilling to accept and tolerate difference, the already dangerous situations aggravated in many areas of the world by religious intolerance will explode. ${ }^{2}$ Conflict is more likely in areas where multiple cultures and religions collide, such as the Indian subcontinent. Such disputes, on the other hand, can be avoided if appropriate methods are developed and followed early on to ensure religious peace. These measures involve urgent educational reforms and curriculum improvement in accordance with the UNESCO education for sustainable development goal. The United nation observed the Interfaith Harmony Week for 2019 under the theme "Sustainable Development through Interfaith Harmony."

According to a recent poll published by the Pakistan Institute of Peace Studies, $30 \%$ of respondents attribute intolerance and society's instability to religious groups, while $28 \%$ blame the government. ${ }^{3}$ The purpose of this research is to examine current Madrasa curricula in terms of interfaith cooperation through content analysis and case studies, as well as to improve existing curricula by incorporating new themes. Additionally, the study examines how the proposed curricula would be implemented in Pakistan's religious seminaries.

\section{ISLAMIC TEACHINGS TOWARDS SUSTAINABLE PEACE}

The Holy Qur'an and the Prophet's Sunnah, which refer to his deeds, words, and indirect commands, are the primary sources of Islamic education. ${ }^{4}$ Both the Holy Qur'an and the Sunnah (Hadith) are descended from the Prophet Muhammad (peace be upon him). ${ }^{5}$ As a great teacher, the Prophet (peace be upon him) provided comprehensive guidance in all spheres of life. ${ }^{6}$ On the other side, Islamic education refers to the direct and practical path to universal peace and togetherness. ${ }^{7}$ Islamic education is fundamentally a peace education that promotes the development of a peaceful culture. Islam's teachings are well aware of human nature and desires. Islam's various components, including its theological, spiritual, legal, social, economic, and political components, are all interrelated and complementary. ${ }^{8}$

\section{THE ROLE OF RELIGIOUS EDUCATION IN INTERFAITH HARMONY}

Despite these peaceful virtues ingrained in Islamic cultural past, it's worth noting that some Islamic civilizations can be violent. To respond to this topic, I would argue that the issue is not with philosophy or theories, but with our interpretation of religion. What generates conflict is the significance we assign to particular ideas and practices. Over time, the majority of believers of most faiths have developed a unique perspective of their own religious heritage. God is considered to be the God of their particular group.

The Qur'an makes it very clear that Islam's fundamental objective is to unite humanity. The Qur'an declares that "mankind was one society," and this your religion is one religion, and I am your Lord; therefore, fulfill your duty to Me."

\section{CONCERNS TOWARDS MADRASSA CURRICULUMS}

The problem with Madrasa curricula is that in the past, classical Islamic scholars on the subcontinent resisted any change in it and was kept out of the rapidity of progress and development in other fields, and the education they imparted was also immune to change and innovation. As a result of this problem, the Madrasa Curriculum faces a number of significant challenges and flaws in today's world. Another issue with Madrassa curricula is that they contain little information on the world's major cultures, civilizations, faiths, or religions.

\section{SHORTCOMINGS IN THE NEW CURRICULUM}

Fiqh al Aqaliat (Islamic law for minorities), which is a key chapter in Islamic Jurisprudence and is worth reading, is not given enough attention in the present curricula of Madaris. The curriculum does not include an examination of historical Resolutions passed and circulated by Muslim rulers in their empires to preserve the

\footnotetext{
${ }^{2}$ Berghout, A. 2008. Meeting the challenges of dialogue: Need for civilisational vision and culturaltransformation. In Dialogue of civilizations and the construction of peace". Kuala Lumpur: Pusat Dialog Peradaban, Universiti Malaya

3. http://www.tajziat.com/quaterly/issue/2017/01/article.php?id=9 accessed on: 28/02/2020

. Marwan Ibrahim, p. 14

5. K. Chisti, Significance and Classification of Hadeeth Multan, Daarul Kutub As-Salfiyyah, 2009), p. 12

6 . Tahir, M. A study of the Teaching strategies used by the Holy Prophet Muhammad

(peace be upon him) Sarhad University Peshawar, 2012), p. 03.

7. L. Navarro, "Peace Education: A Pathway to a Culture of Peace (Center for Peace Education, Philippine, 2010$)$, p. 92.

8. 19 A. Al-Sheha, "Islam is the Religion of peace" (Riyadh: Islamland.org, n.d.), p. 7

9 . Qur'an, 23:52
} 
rights of minorities. The addition of this content will contribute significantly to the promotion of a culture of tolerance among the students.

Tasawuf-related books and other works extolling Islam's spiritual beauty have been ignored largely in Islamic institutions across the subcontinent. Apart from this, despite the critical role of comparative religions in fostering cross-cultural religious communication, the subject is not included in any Madrasa curricula. The comparative is very essential for understanding others and promoting interfaith harmony.

Numerous topics in Islamic law have been revisited by Islamic academics working in post-country governments, and minorities and other religions have been allowed equal rights in nation states as a result of these revisions. Unfortunately, there is no treatment of international law or advancements in Islamic jurisprudence in the context of a post-national state future in the curricula in practice.

\section{ROLE OF MADRASSAS IN PROMOTING HARMONY}

Religious institutions such as madrassas have the ability to foster interfaith and societal harmony among people of various religious backgrounds. The situation is particularly dire in Muslim communities. Madrassas can play an essential role in establishing a culture of reciprocal collaboration as well as intercultural communication among their students, and they have the potential to do so. A Madrassa graduate is regarded as an authoritative religious figure who is capable of giving religious edicts on a wide range of subjects. Madaaris are critical to the general well-being of a community's infrastructure.

\section{SIGNIFICANCE OF THE STUDY}

Today, in the age of globalization, when modern communication tools have shrunk our planet, there is a greater need for long-term harmony and improved understanding among all religions. According to Nasr, modernity and globalization have brought us to a point where we must accept and respect the diversity of religions. People used to live in religiously homogeneous traditional cultures where they rarely encountered beliefs that differed from their own. As a result, they saw their own views as binding and embraced them dogmatically. Today, however, this seclusion is broken, and people are exposed to a variety of cultures and religions. It is difficult, if not impossible, to ignore other traditions nowadays. Believing in the transcendent unity of faiths assists us in peacefully respecting other religions. ${ }^{10}$

The participants to the United Nations Educational, Scientific, and Cultural Organization Summit in Tashkent, Uzbekistan, in September 2000, underlined the necessity of innovative approaches in education for interfaith and intercultural engagement. It is the advice of the UNISCO Summit that the topic's theoretical and political significance be emphasized. On the other hand, according to the experts, madrassas have the potential to play an important role in promoting interfaith cooperation in society. A strong emphasis should be placed on the importance of interfaith collaboration in today's environment. To this point, existing curriculum have been ineffective in promoting interfaith tolerance. Therefore, based on current best practices, we must design madrasa curricular frameworks that reflect common values across faiths while also promoting more intercultural and interfaith understanding in order to achieve greater interfaith understanding and cooperation. The fact that this study is being conducted entirely through content analysis and action research is significant from a methodological standpoint. Aside from that, the study falls short of one of its stated political objectives, which is to foster social integration.

\section{OBJECTIVES OF THE STUDY}

The goal of this research is to assess the existing state of Madrassa curriculum in terms of interfaith harmony in order to give recommendations for expanding and improving current Madrassa curricula by including interfaith subjects, content, and concepts.

\section{MAJOR RESEARCH QUESTION}

How to make Madrassa Curricula responsive to the need of promoting interfaith harmony?

\section{SUBSIDIARY RESEARCH QUESTION}

What concepts/topics of interfaith harmony have been included in Madrassa Curriculum?

How existing Curricula can be enlarged/enriched with reference to interfaith harmony?

How to help Madrassa teachers implementing the proposed curriculum?

${ }^{10}$. Nasr, S. H. Religion and The Order of Nature. "Oxford University Press, London, 1996), pp. 34-35 


\section{BRIEF INTRODUCTION TO THE CURRENT MADRASSA CURRICULA}

To acquire a better understanding of the Dars-e-Nizami curriculum's particular traits and qualities, we shall throw light on the primary courses and books that were used in the Dars-e-Nizami curriculum and that are being taught in the great majority of contemporary Madrasas across the subcontinent:

\begin{tabular}{|c|l|l|}
\hline S/No & Years & \multicolumn{1}{|c|}{ Subjects being taught } \\
\hline 1 & $1^{\text {st }}$ year & $\begin{array}{l}\text { Biography of the Prophet, Conjugation-Grammar Syntax, } \\
\text { Arabic Literature, Chirography, and Chant illation }\end{array}$ \\
\hline 2 & $2^{\text {nd }}$ year & $\begin{array}{l}\text { Conjugation-Grammar, Syntax, Arabic Literature, } \\
\text { Jurisprudence (Fiqa), Logic, Chirography, Quranic Vocalization }\end{array}$ \\
\hline 3 & $3^{\text {rd }}$ year & $\begin{array}{l}\text { Koranic Exegesis, Jurisprudence: (Fiqh), Syntax, Arabic } \\
\text { Literature, Hadith, Logic, Islamic Brotherhood, }\end{array}$ \\
\hline 4 & $4^{\text {th }}$ year & $\begin{array}{l}\text { Quranic Exegesis, Jurisprudence (Fiqa), Principles of } \\
\text { Jurisprudence, } \\
\text { Rhetorics, Hadith, Logic, History, Cant illation, Geography of } \\
\text { the Arab Peninsula and other Islamic } \\
\text { countries) }\end{array}$ \\
\hline 5 & $5^{\text {th } y e a r}$ & $\begin{array}{l}\text { Koranic Exegesis, Jurisprudence, Principles of Jurisprudence, } \\
\text { Rhetoric, Beliefs, Logic, Arabic Literature, Chant illation }\end{array}$ \\
\hline 7 & $6^{\text {th }}$ year & $\begin{array}{l}\text { Tafseer, Jurisprudence, Principles of Interpretation \& } \\
\text { Jurisprudence, Arabic Literature, Philosophy, Chant illation, } \\
\text { Prophet's traditions }\end{array}$ \\
\hline $8^{\text {th }}$ year & $\begin{array}{l}\text { Sayings of the Prophet, Jurisprudence, Belief, law of } \\
\text { inheritance, , Chant illation } \\
\text { Sihah al Sitt'ah (Ten authentic books of Hadiths) }\end{array}$ \\
\hline
\end{tabular}

\section{ANALYSIS}

According to the curriculum outlined above, which is currently implemented in the majority of Pakistan's Madaris, the following critical components for fostering interfaith harmony are missing:

1. There is no basic knowledge of the world's major cultures, religions, or civilizations in the curriculum.

2. There is no course that educates about the ideals that are shared by people of different faiths and cultures.

3. A significant branch of Islamic jurisprudence, Fiqh al Aqaliat (Islamic law for minorities), is not covered in the curricula of most Madaris.

4. The absence of information regarding historical Islamic events or documents dealing with peaceful coexistence with non-Muslims is a significant drawback.

5. There is no evidence available about the human rights rules and resolutions that Muslim governments have passed and put into effect throughout Islamic history.

6. The topic of reconstructing Islamic jurisprudence in a post-national environment is not addressed.

7. The curriculum does not include any reference to minorities' rights as protected by the Pakistani Constitution.

8. There is a lack of a comparative study of faiths, which is becoming an increasingly important instrument for interfaith cooperation in today's society. 


\section{RECOMMENDATIONS}

1. One of the most important things that should be included in madrassa curricula is a foundational level of knowledge and awareness of the world's major cultures, civilizations, and faiths, which would in turn help to raise awareness among learners about the significance of other cultures and religions.

2. Fiqh al Aqaliat (Islamic law for minorities) should be incorporated into the Madrassa curricula.

3. It is necessary to include the Madina Charter as well as the Hudaybia Pact in the Madrassa curriculum.

4. Throughout Islamic history, the resolutions passed and circulated by Muslim monarchs to protect the rights of minorities should be taught in Madrassas.

5. Considering the fundamental foundations of Islamic universal principle " ضرورة تغيُر الحكام بتغير الأزمان وتبدُّل " الأحوال.

6. The rights of minorities guaranteed by the Constitution of the Islamic Republic of Pakistan, under the Articles 20, 21, 25, 26, 27, 28, and 36 of the Constitution, shall be incorporated into the curricula.

7. It is critical that the World Interfaith Harmony Week be observed properly throughout the Islamic Seminaries network. This will heighten understanding of the value of various cultures and civilizations in today's world.

8. As a result of its ability to facilitate cross-cultural religious dialogue, it is advised that the subject of comparative religion be included in Madrassa education.

9. The Islamic Jurisprudence should be taught in the context of the Pakistani Constitution, because many legal issues have changed since the foundation of Pakistan, and the standing of individuals of other faiths is now different from what it was prior to the partition of the sub-continent.

\section{REFERENCE LIST}

1. The Holy Qur'an

2. A. Al-Sheha, "Islam is the Religion of peace" (Riyadh: Islamland.org)

3. A. H. Nayyar, "Madrassah Education Frozen in Time". In the Education and the State - Fifty Years of Pakistan, ed. Pervez Hoodbhoy (Karachi: Oxford University Press, 1998)

4. Berghout, A. 2008. Meeting the challenges of dialogue: Need for civilisational vision and culturaltransformation. In Dialogue of civilizations and the construction of peace" . Kuala Lumpur: Pusat Dialog Peradaban, Universiti Malaya

5. Bouta, S. "Faith-Based Peace-Building: Mapping and Analysis of Christian Muslim and Multi-Faith Actors (Washington DC: Netherland Institute of International Relations, Salam Institute for Peace and Justice, 2005)

6. Dawson C. "Progress and religion" (Peru, Illinois: Sherwood Sugden. 1991)

7. Haar, G. "Bridge or Barrier: Religion, Violence and Visions for Peace” (Boston: Brill, Leiden, 2010)

8. http://www.tajziat.com/quaterly/issue/2017/01/article.php?id=9 accessed on: 28/02/2020

9. Jamal Malik, Colonisation of Islam - Dissolution of Traditional Institutions in Pakistan, (Dhaka: The University Press, 1999),

10. K. Chisti, Significance and Classification of Hadeeth Multan, Daarul Kutub As-Salfiyyah, 2009)

11.Israr Ahmad, The Quran and World Peace (Islamabad, Pakistan, 2003), p.

12. L. Navarro, "Peace Education: A Pathway to a Culture of Peace (Center for Peace Education, Philippine, 2010)

13.Mohammad Muslihuddin, Islami Taleem aur Is Ki Sargazasht (Lahore: Islamic Publications (Private) Limited, 1988)

14. Nasr, S. H. The Heart of Islam: Enduring Values for Humanity. San Francisco: Harper Collins, 2002) 
15. Nasr, S. H. Religion and The Order of Nature. "Oxford University Press, London, 1996)

16.Nadvi, Abul Hasan Ali, " Hindustan ki khadeem darsgahen (Shibli Academy, 1919)

17.Saleem Mansoor Khalid, ed., Deeni Madaris Main Taleem, (Islamabad: Institute of Policy Studies, 2005)

18. Tahir, M. A study of the Teaching strategies used by the Holy Prophet Muhammad (peace be upon him) Sarhad University Peshawar, 2012) 